\title{
TRIK DAN TIPS MENINGKATKAN MUTU PENDIDIKAN DI ERA INDUSTRI 4.0 DALAM MEWUJUDKAN PERGURUAN TINGGI YANG TRANSFORMATIF
}

\author{
Talizaro Tafonao ${ }^{1}$ Fransiskus Irwan Widjaja ${ }^{2}$ Manahan Uji Simanjuntak ${ }^{3}$ Dewi Lidya $S^{4}$ Rini \\ Sumanti Sapalakkai ${ }^{5}$ \\ ${ }^{12345}$ Dosen Sekolah Tinggi Teologi Real Batam \\ e-mail: talizarotafonao@gmail.com¹ irwanwidjaja.fiw@sttrealbatam.ac.id ${ }^{2}$ \\ williamfanuel2010@gmail.com ${ }^{3}$ dewilidyasidabutar30@gmail.com ${ }^{4} \underline{\text { rinigenovita@gmail.com }}{ }^{5}$
}

\begin{abstract}
Abstrak
Tujuan dalam penulisan artikel ini adalah melihat signifikasi tentang koontribusi dosen dalam meningkatkan mutu pendidikan di era digital. Secara empiris, penulis mengamati bahwa masih ditemukan beberapa perguruan tinggi yang mengalami kesulitan dalam menghadapi era industri 4.0. Hal ini terbukti dalam pelaksanakan pendidikan di era digital dan pandemi. Berdasarkan persoalan tersebut, maka melalui tulisan ini, penulis hendak menjelaskan langkah-langkah penting dalam mengatasi berbagai problem tersebut. Metode yang digunakan dalam tulisan ini adalah metode penelitian kualitatif, penulis mengkaji trik dan tips dalam meningkatkan mutu pendidikan di era industri 4.0. Proses analisis yang dilakukan oleh penulis adalah menggunakan berbagai sumber pustaka maupun elektronik yang terpercaya untuk mendukung analisis penulis. Hasil penelitian menemukan beberapa indikator penting, yakni tenaga pendidik/dosen bersahabat dengan teknologi, kemampuan dalam literasi dan kemampuan dalam mempublikasikan karya ilmiah serta kreatif dan inovatif. Dengan temuan seperti ini, maka penulis berkeyakinan bahwa tantangan yang dihadapai oleh perguruan tinggi saat ini dapat teratasi dengan baik sesuai dengan sistem yang telah diterapkan di perguruan tinggi.
\end{abstract}

Kata-kata kunci: Trik dan Tips, Pendidikan, Dosen, Literasi, Industri 4.0

\section{Penduhuluan}

Tulisan ini menjelaskan berbagai upaya dalam meningkatkan mutu pendidikan di era industri 4.0. Penulis melihat bahwa kesempatan dalam membangun mutu pendidikan di era industri ini sangat tepat asalkan hal itu dilakukan berdasarkan ketentuan yang berlaku. Ketentuan yang dimaksud oleh penulis disini adalah semua aktifitas dalam dunia pendidikan harus sesuaikan dengan perkembangan teknologi (digitalisasi). Menurut Astuti, dkk bahwa dalam perkembangan ilmu pengetahuan dan teknologi saat ini selalu terjadi terobosan baru, karena sebagian besar orang telah menangkap kesempatan dan mampu memanfaatkannya dengan baik (Astuti et al., 2019). Karena salah satu ciri khas dari era digital adalah adanya kemudahan dalam melakukan aktifitas dengan menikmati fasilitas yang disediakan oleh kecanggihan teknologi tersebut serta dapat terkoneksi atau saling berhubungan satu dengan yang lain (Setiawan, 2017). Artinya bahwa dengan adanya bantuan dari mesin canggih teknologi dapat membawa perubahan dalam seluruh sistem kehidupan dan pekerjaan manusia termasuk pelaksanaan pendidikan diberbagai instasi. Dalam kajian yang dilakukan oleh Yuliawati menegaskan bahwa perguruan tinggi harus berperan aktif dalam memecahkan berbagai macam masalah (problem solver) yang dihadapi oleh masyarakat 
lewat setiap penelitian yang dilakukan, karena ilmu yang didapatkan melalui penelitian dapat memecahkan setiap masalah yang ada (Yuliawati, 2012).

Selain dituntutan tersebut, Hengki Primayana meminta agar perguruan tinggi lebih berkontribusi meningkatkan daya saing dalam melaksanakan pendidikan yang bermutu (Hengki Primayana, 2016). Salah satu hal yang perlu dibenahi dalam meningkatkan mutu pendidikan diperguruan tinggi adalah manusia, struktur, teknologi dan proses organisasi serta sarana prasarana (Chalid, 2010). Maisah, dkk melihat hal ini sangat penting untuk mendapatkan perhatian dalam meningkatkan mutu pendidikan demi mengejar ketinggalan pada bidang ilmu pengetahuan dan teknologi (Maisah et al., 2020). Tetapi dalam kenyataan masih banyak ditemukan persolan-persolan yang dihadapi oleh perguruan tinggi dalam melaksanakan pendidikan di era industri 4.0. Salah satunya adalah lemahnya para dosen dalam melaksanakan kegiatan tri dharma perguruan tinggi di era digital ini. Hal ini terbukti pada saat penulis melakukan pembinaan penulisan artikel di Sekolah Tinggi Teologi Nias pada tanggal 19 September 2020, para dosen mengakui bahwa belum maksimal dalam melaksanakan tridharma perguruan tinggi khususnya dalam menulis artikel di jurnal online dengan berbagai alasan (Tafonao et al., 2021). Pada hal aktifitas seperti ini salah satu penunjang dalam meningkatkan mutu pendidikan untuk mentransformasikan wajah perguruan tinggi. Jika kita mengaju pada Undang-undang Nomor 14 Tahun 2005 tentang Guru dan Dosen, Dosen dinyatakan sebagai pendidik profesional dan ilmuwan dengan tugas utama mentransformasikan, mengembangkan, dan menyebarluaskan ilmu pengetahuan, teknologi, dan seni melalui pendidikan, penelitian, dan pengabdian kepada masyarakat. Jika hal ini dosen tidak melaksanakan dengan baik sebagaimana tuntutan daripada undang-undang di atas, maka sudah dipastikan bahwa tidak akan terjadi transformasi yang signifikan dalam meningkatkan mutu pendidikan disuatu perguruan tinggi. Sehingga tidak heran, jika sampai saat ini masih banyak perguruan tinggi yang tertatih-tatih dalam memenuhi tuntutan atau aturan yang diterapkan oleh Badan Akreditas Nasional Perguruan Tinggi.

Selain persoalan itu, persoalan lain adalah apa bila dosen tidak melaksanakan hal ini, maka dosen akan mengalami kendala dalam mengurus Jenjang Jabatan Fungsional Akademik (JJA), dimana jabatan akademik ini salah satu syarat bagi dosen untuk bisa mengajar dan melakukan tridharma perguruan tinggi. Dan hal ini juga akan berdampak pada kemajuan dan perkembangan program studi dan institut. Karena salah satu komponen penting disini adalah karya dosen. Dosen merupakan unsur penting dalam sistem pendidikan di perguruan tinggi. Oleh karena itu perguruan tinggi berupaya melakukan peningkatan mutu pendidikan dengan meningkatkan kualifikasi dosen dan tenaga kependidikan serta implementasi sistem penjaminan mutu internal (Hengki Primayana, 2016). Selain itu, dosen juga memiliki peran dan tanggung jawab dalam mewujudkan tujuan pendidikan nasional dengan mencerdaskan kehidupan bangsa, meningkatkan kualitas pendidikan 
serta penguasaan ilmu pengetahuan teknologi (Seprini \& Ningrum, 2014). Oleh sebab itu, dosen diwajibkan menulis buku teks dan jurnal ilmiah serta dipublikasi sebagai salah satu sumber belajar untuk pengembangan budaya akademik serta pembudayaan kegiatan baca tulis bagi Sivitas Akademika (Lian, 2019). Tidak hanya itu, publikasi ini juga salah satu bagian dari bukti luaran dari penelitian dan persyaratan kenaikan jabatan fungsional dosen (Lukman et al., 2019). Disinilah terletaknya revolusi industri 4.0, yang membawa perubahan ke arah yang lebih baik serta dapat mengimbangi perkembangan ilmu pengetahuan dan teknologi. Perbaikan mutu dan kualitas dosen diharapkan mampu menjawab kebutuhan zaman khususnya dalam mempersiapkan mahasiswa menghadapi era revolusi industri tanpa harus menggeser peran dosen sebagai mana mestinya.

Banyak penelitian yang telah membahas mengenai peningkatan mutu pendidikan di perguruan tinggi di era digital, seperti Peningkatan Mutu Pendidikan di Perguruan Tinggi yang dilakukan oleh (Chalid, 2010) yang menjelaskan proses pendidikan dan peningkatan pendidikan di perguruan tinggi. Ada juga kajian yang berjudul Strategi Pengembangan Mutu Perguruan Tinggi yang dibahas oleh (Maisah et al., 2020). Selain itu Manajemen Sumber Daya Manusia dalam Peningkatan Mutu Pendidikan di Perguruan Tinggi dibahas oleh (Hengki Primayana, 2016) dan Kajian Implementasi Tri Dharma Perguruan Tinggi Sebagai Fenomena Pendidikan Tinggi di Indonesia dibahas oleh (Yuliawati, 2012) serta Strategi Pembelajaran dalam Menghadapi Tantangan Era Revolusi Industri 4.0 yang dikaji oleh (Astuti et al., 2019).

Kelima kajian di atas sama-sama menjelaskan upaya-upaya serta strategi dalam meningkatkan mutu pendidikan di perguruan tinggi di era 4.0. Namun para peneliti belum menjelaskan bagaimana seharusnya para dosen berupaya memaksimal diri dalam meningkatkan mutu pendidikan di perguruan tinggi melalui penelitian dan pengabdian seperti tertuang dalam Undang-ndang Nomor 14 Tahun 2015 tentang Guru dan Dosen pada pasal 60 dinyatakan bahwa dalam melaksanakan tugas keprofesionalan, dosen berkewajiban antara lain melakukan publikasi ilmiah sebagai salah satu sumber belajar (Lukman et al., 2019). Oleh karena itu, penulis mengkaji hal ini tentang topik memberi pemahaman kepada semua para pendidik atau dosen tentang tugas dan tanggung jawab dalam meningkatkan mutu pendidikan di era industri 4.0 dalam mewujudkan perguruan tinggi yang transformatif serta melengkapi kajian para penelitian sebelumnya.

Berdasarkan latar belakang masalah di atas maka yang menjadi rumusan masalah dalam tulisan ini adalah apa upaya yang dilakukan oleh dosen dalam meningkatkan mutu pendidikan di era industri 4.0 dalam mewujudkan perguruan tinggi yang transformatif. Dengan rumusan masalah tersebut maka tujuan penulisan artikel ini adalah mendorong para dosen untuk berkontribusi dalam meningkatkan mutu pendidikan di era digital melalui aktifitas atau karya nyatanya. 


\section{Metode}

Metode yang dipakai dalam tulisan ini adalah metode kualitatif. Penulis melakukan kajian analisis dengan memperbanyak informasi, mencari hubungan ke berbagai sumber, membandingkan, dan menemukan hasil atas dasar data sebenarnya (tidak dalam bentuk angka). Selanjutnya, penulis menggunakan berbagai sumber-sumber literatur-literatur baik jurnal, buku dan bahan referensi lainnya yang terpercaya untuk mendukung analisis penulis dalam artikel ini.

\section{Hasil dan Pembahasan}

Dalam meningkatkan kualitas pendidikan di era industri 4.0 merupakan suatu tantangan tersebesar bagi setiap perguruan tinggi saat ini, tetapi disamping itu juga ada peluang besar bagi yang mau mengubah cara kerjanya dalam menghadapi perubahan tersebut. Penulis mengamati bahwa bangsa Indonesia telah melewati berbagai revolusi yang ada, mulai dari revolusi industri 1.0, 2.0, 3.0, sampai pada industri 4.0. Lantas apa hubungannya dengan industri 4.0 dengan pendidikan? Revolusi industri 4.0 secara tidak langsung telah mengubah cara pandang tentang pendidikan di Abad 21 saat ini. Bergesernya pendidikan Abad 21 saat ini tidak hanya sekadar konsep cara mengajar, tetapi jauh yang lebih esensial, yakni perubahan cara pandang terhadap konsep pendidikan itu sendiri (Surani, 2019). Akibat pergeseran ini telah mengubah cara pandangan masyarakat dalam memandangan keberhasilan dan mutu pendidikan (Unwanullah, 2015). Sehingga dalam memperhatikan pembangunan pendidikan di Indonesa saat ini menjadi prioritas utama, karena pendidikan memegang peranan sangat penting dalam peningkatan kualitas sumber daya manusia.

Selain itu, pendidikan merupakan upaya yang bisa mempercepat pengembangan potensi manusia untuk mampu mengemban tugas yang dibebankan kepadanya. Oleh karena itu, dalam menghadapi era industri 4.0 ini membutuhkan Sumber Daya Manusia (SDM) yang memiliki kompetensi dan professional (Surani, 2019). Dalam mewujudkan hal tersebut pemerintah berupaya meningkatkan kualitas sumber daya manusia melalui pengembangan dan perbaikan kurikulum, perbaikan sarana pendidikan, pengembangan dan pengadaan materi ajar, serta pelatihan bagi dosen/guru dan tenaga kependidikan lainnya. Sebab menurut Muhammad mengatakan bahwa isi pembelajaran pabad 21 ini harus selalu menyesuaikan dengan perubahan termasuk di era industri 4.0. Pembelajaran yang diharapkan adalah mampu memenuhi keterampilan abad 21 (21st century skills), yakni pembelajaran yang menghasilkan inovasi, berpikir kritis dan kreatifitas (Muhammad Yahya, 2018). Artinya, bahwa dalam meningkatkan mutu pendidikan disuatu perguruan tinggi banyak hal yang harus diperhatiakan dan dilibatkan. Berangkat dari penjelasan itu, maka dalam tulisan ini penulis menguraikan berbagai hal yang 
berkaitan dengan trik dan tips dalam meningkatkan mutu pendidikan di era industri 4.0 dalam mewujudkan perguruan tinggi yang transformatif, yaitu:

1. Dosen bersahabat dengan teknologi

Kehadiran teknologi saat ini menjadi salah satu penunjang dalam melakukan seluruh aktivitas yang dilakukan oleh masyarakat terlebih khusus para pendidik. Selain menunjang aktifitas, perkembangan teknologi memberi kemudahan kepada siapapun dalam mendapatkan berbagai informasi dan pengetahuan baru melalui situs internet. Tetapi disamping itu pendidikan mengalami perubahan yang sangat signifikan di era industri 4.0. Sehingga secara tidak langsung perkembangan teknologi ini sangat berdampak pada peran pendidik, dimana para pendidik/dosen mengalami pergeseran tersendiri dari sebelumnya sebagai satu-satunya sumber ilmu, sekarang tidak lagi demikian. Menurut hemat Nizam bahwa alangkah baiknya para dosen mendorong setiap mahasiswa untuk mencari ilmu dari berbagai sumber khususnya dalam perkembangan teknologi ini (Nizam, 2020). Ini lah yang ditegaskan oleh Mohamad Nasir (Menteri Riset, Teknologi dan Pendidikan Tinggi) bahwa dalam menghadapi revolusi industri 4.0, peran dosen dalam perguruan tinggi sangat penting dan strategis. Di era digitalisasi, seorang dosen harus mampu beradaptasi dengan kemajuan teknologi serta dosen memiliki kompetensi inti keilmuan (core competence) yang kuat, mempunyai soft skill, critical thinking, kreatif, komunikatif dan mampu berkolaborasi dengan mahasiswa (Fatimah, 2018). Oleh karena itu, kesiapan perguruan tinggi dalam menghadapi tantangan di era industri 4.0 dapat diwujudkan melalui upaya dalam menciptakan Sumber daya Manusia (Dosen) serta output (mahasiswa dan Lulusan) yang berkualitas sehingga mendorong Perguruan Tinggi di Indonesia menjadi Perguruan Tinggi yang mampu bersaing dalam kanca Internasional (Harto, 2018).

\section{Dosen meningkatkan kemampuan dalam berliterasi}

Dosen tidak hanya menguasai materi pembelajaran, tetapi juga dosen harus memiliki kemampuan dalam literasi. Salah satu solusi dalam era industri 4.0 adalah meningkatkan kemampuan dalam menguasi literasi. Menurut Yamin bahwa literasi adalah bagian tidak terpisahkan dari modal penguatan Sumber Daya Manusia (SDM) di perguruan tinggi. Pada umumnya literasi identik dengan aktivitas membaca dan menulis (Yamin, 2018). Penulis memperhatikan bahwa aktivitas literasi tidak hanya berhenti sampai membaca dan menulis, tetapi literasi yang dimaksud di era industri 4.0 adalah menguasai literasi baru, yakni (1). Literasi data. Literasi data adalah akitivitas membaca, menganalisa dan menggunakan informasi dari data dalam dunia digital. Jadi para dosen dan mahasiswa diharapkan mampu mengolah banyaknya data dan informasi yang tersedia di era digital sebagai sumber ilmu, (2). Literasi teknologi. Dosen dan mahasiswa yang tidak memiliki literasi teknologi memadai akan mengalami kekalahan dalam 
persaingan hidup. Sebab literasi teknologi adalah kemampuan untuk memahami sistem kerja mesin dengan aplikasi teknologi, (3) Literasi sumber daya manusia. Dosen yang memiliki kemampuan dalam memanfaatkan ilmu dan teknologi hendaknya ilmu tersebut digunakan untuk membahagiakan dan menyejahterakan manusia yang ada di era industri 4.0 ini. Berdasarkan penjelasan dan uraian ini, Hasnadi melihat bahwa budaya literasi dapat bermanfaat untuk mengetahui dan memahami informasi yang benar dari media atau orang lain (Hasnadi, 2019).

3. Dosen yang produktif dalam menulis dan publikasi karya ilmiah

Salah satu tuntutan pemerintah kepada dosen saat ini adalah meningkatkan kemampuan dalam menulis dan publikasi (penelitian). Kebutuhan menulis menjadi indikator penting dalam meningkatkan kualitas pendidikan di perguruan tinggi. Sehingga tidak heran jika sampai saat ini semua perguruan tinggi dituntut untuk melaksanakan Tridharma Perguruan Tinggi, yaitu pendidikan, penelitian, dan pengabdian masyarakat (Nafilatur Rohmah, Muhammad Huda A.Y, 2016). Menurut hemat Yamin bahwa salah satu tugas dan tanggung jawab perguruan tinggi saat ini adalah mendorong para dosen untuk mengembangkan potensi diri dalam bidang publikasi. Semakin aktif dalam melakukan publikasi berarti semakin menghidupkan suasana akademis sebagai cerminan dari tridharma perguruan tinggi serta memberikan kontribusi bagi pengembangan keilmuan (Yamin, 2018). Berdasarkan penjelasan ini, Nafilatur, dkk, menanggapi bahwa dosen menulis karya ilmiah memiliki tujuan lebih spesifik yakni: (1) menyampaikan gagasan atau ide, (2) membuat bahan ajar, (3) memenuhi syarat kenaikan pangkat (pengajuan jabatan fungsional) (Nafilatur Rohmah, Muhammad Huda A.Y, 2016). Dengan melihat tujuan ini maka dosen didorong untuk menulis. Menurut Undang-undang Nomor 14 Tahun 2005 bahwa tugas utama dosen adalah mentransformasikan, mengembangkan, dan menyebarluaskan ilmu pengetahuan, teknologi, dan melalui pendidikan, penelitian, dan pengabdian kepada masyarakat (Tafonao \& Widjaja, 2021).

\section{Dosen meningkatkan kreatif dan inovatif}

Di era industri 4.0 ini sangat dibutuhkan para dosen yang memiliki jiwa kreatif dan inovatif. Kreatif dan inovatif merupakan bagian tidak bisa terpisahkan dari pemikiran sivitas akademika terutama dosen dan mahasiswa, dimana kreatif dan inovatif salah satu kemampuan untuk menghasilkan hal baru yang belum pernah ada sebelumnya. Ide kreatif dan inovatif tidak lahir begitu saja tetapi muncul pada saat menghadapi berbagai tantangan dan peluang. Tantangan dan peluang yang ada saat ini adalah sistem pengajaran harus mengikuti perkembangan zaman. Salah satu tuntutannya dari era industri 4.0 menurut Boiliu, dkk adalah dosen harus mengubah cara mengajarnya dengan berorientasi pada perkembangan atau kemampuan anak (Boiliu et al., 2021). Dengan adanya kreativitas dan inovatif dari dosen maka dapat mencapai tujuan pembelajaran yang sesungguhnya sehingga hal ini sangat berdampak pada berprestasi mahasiswa. Hal yang sama 
disampaikan oleh Muslimin dan Mutakallim bahwa kreativitas dalam pembelajaran dapat menumbuhkan semangat mahasiswa dengan menerapkan sistem pembelajaran berbasis penggunaan teknologi (Mutakallim, 2019). Tetapi dosen tidak hanya sebatas mentransfer ilmu kepada mahasiswa, tetapi yang paling penting dalam pendidikan dan pembelajaran adalah mentransferkan nilai-nilai (values) sehingga sampai saat ini dosen-dosen dituntut terus untuk memiliki perilaku yang baik (Angelina, 2015).

Berdasarkan penjelasan ini maka menurut hemat penulis bahwa dosen yang kreatif dan inovatif adalah mampu menghasilkan hal baru melalui pengalaman belajar kemudian dituangkan dalam karya nyata serta mampu mengelaborasi dan mengembangkan menjadi suatu sumber belajar bagi semua orang, sekaligus menjadi solusi dalam memecahkan setiap masalah yang ada saat ini. Oleh karena itu, guru atau dosen harus melek dengan teknologi, karena melalui teknologi dapat memberikan pengetahuan, memudahkan dalam mencari bahan pembelajaran serta menarik perhatian mahasiswa untuk memahami penjelasan para dosen dengan hal-hal baru.

\section{Kesimpulan}

Berdasarkan kajian ini, penulis melihat bahwa salah satu faktor yang mendorong peningkatan mutu pendidikan di era digital adalah dosen. Tidak berarti hal-hal lain tidak penting tetapi secara spesifik dalam kajian ini melihat bahwa kontribusi para pendidik di era 4.0 ini sangat penting. Jika peran dosen memiliki signifikan dalam mengubah wajah perguruan tinggi menjadi lebih baik maka hendaknya para pengelola perguruan tinggi saat ini meninjau kembali sistem yang telah terapkan selama ini, apakah sistem tersebut telah jalan atau sudah sesuai dengan perkembangan atau tidak serta peraturan-peraturan yang berlaku sebagaiman penjelasanpenjelasan dalam artikel ini.

\section{Daftar Pustaka}

Angelina, D. (2015). Dosen Harus Open Minded, Kreatif, dan Inovatif. Koran Sindo.

https://nasional.sindonews.com/berita/1018000/162/dosen-harus-open-minded-kreatifdan-inovatif

Astuti, Waluya, S. B., \& Asikin, M. (2019). Strategi Pembelajan Dalam Menghadapi Tantangan Era Revolusi 4.0. Seminar Nasional Pascasarjana 2019, 2(1), 469-473. https://proceeding.unnes.ac.id/index.php/snpasca/article/view/327

Boiliu, N. I., Widjaja, F. I., Nugroho, F., Siahaan, H. E., \& Harefa, O. (2021). Pendidikan Humanis Sebagai Pendekatan Pembelajaran di Era Revolusi Industri 4 0. In Sosial, Pendidikan dan Agama Sebagai Pondasi Dalam Mewujudkan "Maju Bersama Kita Berjaya” (pp. 741-758). Marpoyan Tujuh. 
Chalid, S. (2010). Peningkatan Mutu Pendidikan Di Perguruan Tinggi. Paper Seminar Sistem Informasi Manajemen, 1(1), 115-120.

Fatimah, S. (2018). Era Digital, Dosen Harus Mampu Beradaptasi dengan Teknologi. Oknews. https://www.mendeley.com/reference-management/web-importer/

Harto, K. (2018). Tantangan Dosen Ptki Di Era Industri 4.0. Jurnal Tatsqif, 16(1), 1-15. https://doi.org/10.20414/jtq.v16i1.159

Hasnadi. (2019). Membangun Budaya Literasi Informasi pada Perguruan Tinggi. Semdi Unaya, 3(1), 610-620. http://jurnal.abulyatama.ac.id/index.php/semdiunaya

Hengki Primayana, K. (2016). Manajemen Sumber Daya Manusia Dalam Peningkatan Mutu Pendidikan Di Perguruan Tinggi. Jurnal Penjaminan Mutu, 1(2), 7.

https://doi.org/10.25078/jpm.v1i2.45

Lian, B. (2019). Tanggung Jawab Tridharma Perguruan Tinggi Menjawab Kebutuhan Masyarakat. Prosiding Seminar Nasional Pendidikan Program Pascasarjana Universitas PGRI Palembang, 2, 100-106.

Lukman, Ahmadi, S. S., Manalu, W., \& Hidayat, D. S. (2019). Pedoman Publikasi Ilmiah Pedoman 2019. Direktorat Pengelolaan Kekayaan Intelektua. http://risbang.ristekdikti.go.id

Maisah, M., Fauzi, H., Aprianto, I., Amiruddin, A., \& Zulqarnain. (2020). Strategi Pengembangan Mutu Perguruan Tinggi. Jurnal Ilmu Manajemen Terapan (JIMT), 1(5), 416424. https://doi.org/10.31933/JIMT

Muhammad Yahya, H. (2018). Era Industri 4.0: Tantangan dan Peluang Perkembangan Pendidikan Kejuruan Indonesia. Universitas Negeri Makassar, 1-27. https://core.ac.uk/download/pdf/154762984.pdf

Mutakallim, A. A. M. (2019). Kreativitas dalam Pembelajaran Creativity in Learning. Tarbawi, Jurnal Pendidikan Agama Islam, 4(1), 72-85.

Nafilatur Rohmah, Muhammad Huda A.Y, K. (2016). Strategi Peningkatan Kemampuan Dosen dalam Penulisan Karya Ilmiah ( Studi Multi Kasus pada UNISDA dan STAIDRA di Kabupaten Lamongan). Jurnal Pendidikan, 1(7), 1312-1322.

Nizam. (2020). Dosen Bukan Satu-Satunya Sumber Ilmu. IItjen Kemendikbud.

https://itjen.kemdikbud.go.id/public/post/detail/dosen-bukan-satu-satunya-sumber-ilmu Seprini, \& Ningrum, I. S. (2014). Strategi Meningkatkan Kompetensi Dosen Universitas Pasir Pengaraian Melalui Pendidikan dan Pelatihan. Jurnal Ilmiah Cano Ekonomos, 3(2), 117-138. http://e-journal.upp.ac.id/index.php/Cano/article/view/387

Setiawan, W. (2017). Era Digital dan Tantangannya. Seminar Nasional Pendidikan, 1-9.

Surani, D. (2019). Studi Literatur: Peran Teknologi Pendidikan dalam Pendidikan 4.0. Prosiding Seminar Nasional Pendidikan FKIP, 2(1), 456-469. 
Tafonao, T., \& Widjaja, F. I. (2021). Pembinaan dan pelatihan penulisan karya ilmiah di kalangan dosen Sekolah Tinggi Teologi Kadesi Yogyakarta ( Coaching and training of writing scientific papers to lecturers of Sekolah Tinggi Teologi Kadesi Yogyakarta). Yumary: Jurnal Pengabdian Kepada Masyarakat, 1(3), 127-134.

Tafonao, T., Widjaja, F. I., \& Simanjuntak, F. (2021). PEMBINAAN KARIR DOSEN: Trik dan Tips Menulis Karya Ilmiah dalam Meningkatkan Kompetensi Dosen di Sekolah Tinggi Teologi Nias. PROSIDING SEMINAR NASIONAL PENELITIAN DAN PENGABDIAN 2021, $1109-1118$.

Unwanullah, A. (2015). Industrialisasi Dan Tantangannya Pada Sektor Pendidikan. Jurnal Economia, 11(2), 107. https://doi.org/10.21831/economia.v11i2.8237

Yamin, M. (2018). Kebijakan Literasi Untuk Meningkatkan Produktivitas Publikasi Di Perguruan Tinggi. JAS-PT Jurnal Analisis Sistem Pendidikan Tinggi, 2(1), 19. https://doi.org/10.36339/jaspt.v2i1.120

Yuliawati, S. (2012). Kajian Implementasi Tri Dharma Perguruan Tinggi Sebagai Fenomena Pendidikan Tinggi di Indonesia. Widya, 2(3), 28-33. 